УДК 091"15":027.54(477-25)НБУВ

Підгорбунський Микола Анатолійович, кандидат історичних наук, доцент, доцент Київського національного університету культури і мистецтв nikolauspidg@gmail.com

ORCID 0000-0002-2678-5147

\title{
АРХЕОГРАФІЧНИЙ АНАЛІЗ УКРАЇНСЬКИХ РУКОПИСНИХ ПІВЧИХ ЗБІРНИКІВ ТРІОДЕЙ ХVI СТ.
}

Метою статті $є$ аналіз рукописних збірок Тріодей в колекції Інституту рукопису НБУВ; проведення археографічного опису та виявлення характерних особливостей в півчих збірниках української Православної церкви в XVI ст. Методологія дослідження включає системний аналіз, що дав можливість проаналізувати та дослідити рукописні півчі збірники. Для окреслення часових і кількісних характеристик проаналізованого матеріалу було вжито статистичний та хронологічний методи. Наукова новизна - полягає у з'ясуванні відмінностей: в оформленні тексту рукописних збірниках, у використанні екфонетичного та невменного нотопису, та поступовій модернізації українського півуставу. Висновки. Археографічний опис рукописних Тріодей дав змогу виявити загальні риси в оформленні стародавніх збірок. Тексти рукописних збірників написані українським півуставом. Кожний розділ починається заголовком, який написаний кіноварною в'яззю, а закінчення кожного розділу має певне оформлення у вигляді колофону, або невеликого графічного зображення. Визначені певні відмінності: в оформленні богослужбових текстів та поступовій модернізації українського півуставу. Екфонетична і невменна нотації в півчих рукописних збірниках Тріодях XVI ст. має певну варіативність. Церковні ієрархи не вважали це порушенням певних норм, але будь-яка варіативність по відношенню до текстів богослужіння була недопустима, оскільки вони були канонічними. Невирішеним питанням залишається розшифрування екфонетичного та невменного нотопису, який супроводжує тексти півчих збірників Тріодей. Вирішити цю проблему можливо при активній співпраці українських вчених-медієвістів з науковцями західноєвропейських країн. колофони.

Ключові слова: рукописні Тріоді, екфонетична та невменна нотація, український півустав, ініціали,

Подгорбунский Николай Анатольевич, кандидат исторических наук, доцент, доцент Киевского национального университета культуры и искуссть

Археографический анализ украинских рукописных певческих сборников Триодей XVI ст.

Целью статьи является анализ рукописных сборников Триодей в коллекции Института рукописи НБУВ; проведение археографического описания и выявления характерных особенностей в певчих сборниках украинской Православной церкви в XVI в. Методология исследования включает системный анализ, который дал возможность проанализировать и исследовать рукописные певчие сборники. Для определения временных и количественных характеристик проанализированного материала были использованы статистический и хронологический методы. Научная новизна - заключается в выяснении различий: в оформлении текста рукописных сборниках, в использовании екфонетической и невменной нотации, и постепенной модернизации украинского полуустава. Выводы. Археографическое описание рукописных Триодей позволило выявить общие черты в оформлении древних сборников. Тексты рукописных сборников написаны украинским полууставом. Каждый раздел начинается заголовком, который написан киноварной вязью, а окончание каждого раздела имеет определенное оформление в виде колофона или небольшого графического изображения. А также выявлены определенные различия: в оформлении богослужебных текстов и постепенной модернизации украинского полуустава. Екфонетическая и невменная нотации в певчих рукописных сборниках Триодях XVI в. имеет определенную вариативность. Церковные иерархи не считали это нарушением определенных норм, но любая вариативность по отношению к богослужебным текстам недопускалась, поскольку они были каноническими. Нерешенным вопросом остается расшифровка екфонетической и невменной нотации, которая сопровождает тексты певчих сборников Триодей. Решить эту проблему возможно при активном сотрудничестве украинских ученых-медиевистов с учеными западноевропейских стран.

Ключевые слова: рукописные Триоди, екфонетическая и невменная нотация, украинский полуустав, инициалы, колофоны.

Pidhorbunskyi Mykola, Candidate of Historical Sciences, Associate Professor, Associate Professor of Kiev National University of Culture and Arts

Archaeographic analysis of Ukrainian manuscripts of singing collections Triodey XVI century

The purpose of the article is to analyze the Triodey manuscript collections in the collection of the NBUV Manuscript Institute; conducting an archaeographic description and identifying characteristic features in the songbooks of the Ukrainian Orthodox Church in the 16th century. The methodology includes system analysis, which made it possible to analyze and

(C) Підгорбунський М.А., 2019 
explore handwritten singing collections. Statistical and chronological methods were used to determine the temporal and quantitative characteristics of the analyzed material. Scientific novelty is to clarify the differences: in the design of the text of handwritten collections, in the use of ekfoneticheskoy and irrelevant notation, and the gradual modernization of the Ukrainian half-order. Conclusions. The archaeographic description of the manuscript Triodeus made it possible to identify common features in the design of ancient collections. The texts of handwritten collections were written by the Ukrainian half-mouth. Each section begins with a heading written in cinnabar script, and the end of each section has a certain design in the form of a colophon or a small graphic image. And also certain differences were revealed: in the design of liturgical texts and the gradual modernization of the Ukrainian half-order. Ephonetic and irrelevant notations in singing manuscript collections of the Triode of the 16th century has a certain variability. Church hierarchs did not consider this a violation of certain norms, but any variability in relation to liturgical texts was not allowed, since they were canonical. The unresolved issue is the decoding of ekfoneticheskoy and irresponsible notation, which accompanies the texts of the songbooks Triodey. It is possible to solve this problem with the active cooperation of Ukrainian medieval scholars with scientists from Western European countries. colophons.

Key words: handwritten Triodi, ekfoneticheskaya and irresponsible notation, Ukrainian half-mouth, initials,

Актуальність теми дослідження пов'язана зі зростаючим інтересом до історичного минулого української Православної церкви. Головною подією, яка сприяла активізації діяльності вчених у цьому напрямку було утворення Київської митрополії Української православної церкви (Православної церкви України) 15 грудня 2018 р. на визнаному Вселенським патріархатом помісному соборі. Важливою складовою історії та духовної культури українського народу є стародавній церковний та богослужбовий спів, починаючи з часів Київської Русі і до сьогодення. Церковний спів 3 X по XVI ст. залишається малодослідженим, що в свою чергу, стримує рух в напрямку розшифровки екфонетичного та невменного нотописів української Православної церкви. Тому, грунтовне дослідження колекцій богослужбових півчих збірок, стан яких 3 кожним роком погіршується, є важливим завданням вчених-медієвістів.

Аналіз останніх досліджень і публікацій. Першими, хто досліджував рукописні збірки в Україні, були Д. І. Щербаківський «Золотарська оправа книжки в XVI-XIX століттях на Україні» та I. С. Свенціцький «Прикраси рукописів Галицької України XVI-ого віку» [9; 6]. Грунтовна робота П. М. Жолтовського «Українська рукописна книга та їі оздоблення» була присвячена дослідженню оформленню українських рукописів [2]. В сучасний період дослідженням рукописних збірок займалися О. А. Іванова та Л. А. Дубровіна. Вони зробили аналіз рукописних півчих збірок Міней, Тріодей і Октоїхів у своїх працях «Кирилична рукописна книга XVI ст. 3 фондів Інституту рукопису Національної бібліотеки України імені В. І. Вернадського» та «Півчі богослужбові книги у репертуарі рукописних книг XVI ст. у фондах Інституту рукопису Національної бібліотеки України імені В. І. Вернадського» [3; 4]. О. А. Іванова та Л. А. Дубровіна сконцентрували свою увагу на загальному опису рукописів, при цьому залишивши поза увагою екфонетичний та невменний нотопис, який супроводжує текст півчих збірок.

Метою статті $є$ аналіз рукописних збірок Тріодей XVI ст. 3 колекції Інституту рукопису НБУВ, проведення археографічного опису та виявлення характерних особливостей в богослужбових півчих збірниках.

Виклад проблеми. Більшість рукописних книг в XVI ст. мали переважно сакральний характер. Це були твори релігійного змісту, зокрема: богослужбові та небогослужбові (четьї) книги; твори отців Церкви - повчання та бесіди. Важливе місце серед них займали рукописні півчі книги Православної церкви. Серед унікальних рукописних зібрань XVI ст., які зберігаються у колекції Інституту рукопису НБУВ, є богослужбові півчі збірки Тріоді. Ця колекція півчих богослужбових книг представлена 23 рукописами, серед них молдавські, сербські, російські та українські збірки. Нашим завданням є проведення археографічного аналізу саме українських рукописних збірок, їхня кількість становить 12 пам'яток. На жаль, чотири з них майже не збереглися і мають тільки по одному рукописному аркушу. Це Тріоді пісні ф. 235, № 14; ф. 235, № 15; ф. 235, № 16; ф. 235 , № 17 $[12 ; 13 ; 14 ; 15]$.

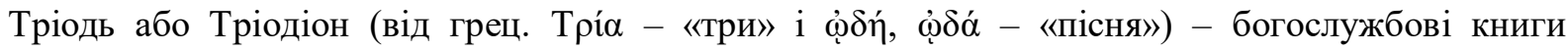
Православної церкви, що містять трьохпісенні канони (тріпеснци). Тріодь походить від єдиного комплексу співів тропарно-стіхірного типу, він склався приблизно в VII ст. і мав назву Тропологій

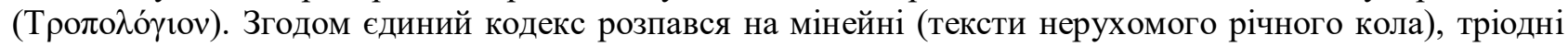
(тексти рухомого великоднього кола) частини і Октоїх (тексти седмичного кола) [7].

Першим укладачем цих канонів був великий святий Косма, єпископ Маюмський, який жив в першій половині VIII ст. Він написав ці канони для Великої седмиці: Великого понеділка, Великого вівторка, Великої середи, Великого Четвірка, Великого п'ятка і четверопесенца Великої суботи 3 шостої по дев’яту пісню. Згодом, за його прикладом інші півчі, в першу чергу, Йосип і Феодор 
Студити (IX ст.), складали трьохпісенні канони для наступних тижнів святої Чотиридесятниці. Всі ці богослужбові тексти були зібрані разом, доповнені стихірами і канонами та передані в Студійську обитель. Так утворився ряд служб, що отримав назву Тріодіон. Спочатку Тріодь існувала у вигляді єдиного збірника, а потім була розділена на дві частини - Тріодь пісну та Тріодь цвітну. Тріодь містить чин богослужіння в продовженні 18 тижнів: 10 тижнів (70 днів) до Великодня - Пісна Тріодь, і 8 тижнів після Пасхи - Цвітна Тріодь [1].

Тріодь пісна містить в собі пісні переважно покаянного змісту на дні Великого посту 3 підготовчими седмицями до нього і Страсної седмиці. Вона починається 3 неділі про Митаря $\mathrm{i}$ Фарисея, містить служби трьох підготовчих тижнів до Великого Посту та служби власне Великого Посту до утреньої п’ятниці шостого тижня Посту включно. Це піснеспіви в основному авторів VIIIIX ст., серед яких: Андрій Критський, Косма Маюмський, Іоанн Дамаскін, імператор Лев Мудрий, Феофан Начертаний.

Як вже зазначалося, Тріоді охоплюють коло рухомих свят року і залежать від дня святкування Пасхи: від підготовчих седмиць до Великого посту і до першої неділі після свята Святої Трійці (тобто до неділі Всіх святих). Перші дві підготовчі седмиці Тріодь використовується тільки в недільній службі на Неділю про Митаря і Фарисея і на Неділю про блудного сина, а починаючи зі служби на суботу (передостання перед Великим постом) перед Тижнем про Страшний Суд - щодня.

Співи Цвітної Тріоді, так само як і Пісної, складені святими отцями, деякі імена яких залишилися невідомими. Багато піснеспівів Цвітної Тріоді належать святому Іоанну Дамаскіну, в тому числі і одне 3 найбільш відомих його творінь - канон на Святу Пасху. Зібрання піснеспівів в одну книгу приписується тим же особам, які склали і Пісну Тріодь, тобто святим Феодору і Йосипу Студиту. Однак і після них зміст Цвітної Тріоді поповнювався аж до XIV ст. Так, ії доповнив синаксаріями Никифор Калліст [8].

Назва «Цвітна тріодь» походить від свята Входу Господнього в Срусалим або Цвітна Неділя, оскільки в ранній богослужбової традиції друга частина Тріоді, пов'язаної зі святом Входу Господнього в Єрусалим. Цвітна Тріодь, інакше звана Пентикостаріон (від грец. П'ятидесятниця), містить служби від Тижня Великодня до Тижня Всіх Святих, тобто П’ятидесятниці і ще одного тижня після П’ятидесятниці [7].

Цвітна Тріодь починалася зі служби вечірні п’ятниці, напередодні Лазаревої суботи і продовжувалася до неділі Всіх святих (перша неділя після Трійці) включно. Цей поділ присутній в усіх слов'янських Тріодях до другої половини XVII ст. Після Никонівської реформи відбулися зміни згідно з грецькими богослужбовими книгами. Від другої половини XVII ст. Пісна Тріодь закінчувалася службою у Велику Суботу, а Цвітна починалася від Пасхального тижня.

Характерною ознакою Тріоді Пісної $є$ наявність у ній канонів 3 трьох пісень у щоденних службах; у недільні дні канони містять 8-9 пісень. Саме канони, зазначає дослідниця О. А. Іванова, $\epsilon$ основною складовою Тріодей. Крім канонів, Тріодь містить звичайні піснеспіви: стихіри, прокімни, сідальні, світильні. Від Октоїха, де в службі одного дня наявні піснеспіви одного гласу, Тріодь відрізняється наявністю в ній піснеспівів різних гласів [4].

Православна Тріодь в Київській Русі $є$ однією із найдавніших богослужбових книг, що зберіглася в рукописах 3 XII-XIII ст. Ці рукописи відображають початкову стадію розвитку давньоруської співочої традиції. Текст піснеспівів у перших нотованих збірниках був частково грецький, частково старослов'янський. Д. В. Разумовський зазначає, що в середині ХIII ст. в церкві Святої Богородиці лівий клірос виконував піснеспіви грецькою мовою, а правий - слов'янською. Виконання піснеспівів грецькою мовою, на думку Д. В. Разумовського, підтримувалося ієрархами грецького походження, які були малознайомі зі слов'янською мовою і письмом. Не зважаючи на ці обставини обидва тексти піснеспівів (грецький і слов'янський) в перших нотованих збірниках писалися старослов'янською мовою [5].

Зміст у рукописних тріодях поділяється на розділи та складові елементи, що відповідають тим чи іншим структурним особливостям церковного співу на богослужінні. В цих збірниках виокремлюються назви служб у колонтитулі та назви піснеспівів на бічних полях. Так, богослужіння в тріодях розміщуються за седмицями (тижнями), заголовки до седмиць написані в'яззю або в рядок [3].

Проводячи археографічний опис Тріоді пісної (ф. 312, № 74), можна виокремити певні особливості оформлення даного рукопису. Так, цей збірник має 177 арк., де бракує кількох зошитів на початку і наприкінці рукопису. Формат рукопису Папір - $2^{\circ}$ (290 x 195). Текст рукопису написаний українським раннім півуставом, який супроводжується екфонетичними та невменними знаками. Ініціали виділені кіновар'ю та прикрашені завитками та розчерками. Збірник має три почерки: 1) 
1 арк. - 6 зв.; 30 арк. - 71 зв.; 2) 7 арк. - 29 зв.; 3) 72 арк. - 177 зв. Оправа рукопису - дерево, обтягнуте шкірою 3 тисненням, застібки не збереглися. Верхня обкладинка тріснута навпіл i тримається на шкірі. На нижньому полі 1 арк. скорописом написано «Кіево-Софійской бібліотеки 1854». Під цим записом стоїть печатка «Бібліотека Кіево-Софійского Собора № 83». Заголовки розділів написані кіноварною в'яззю, закінчення прикрашені колофоном (6 зв.). Закінчення тексту на 71 зв. оформлено у вигляді хреста, під текстом зображена рука, яка тримає чашу. Збірник починається тропарями третьої пісні канону утрені середи першої седмиці Великого посту. Закінчується рукопис четвертою піснею канону служби Похвали Пресвятої Богородиці у суботу п'ятої седмиці. Цей рукопис також цінний тим, що на бічних полях його аркушів є більш пізнє зображення нотного стану з нотами та певними знаками. Так, 108 зв. на бічному лівому полі зображено нотний стан 3 нотами, 109 арк. та 113 арк на нижньому і бічному полі нотний стан зі знаками, 110 зв. на бічному лівому полі зображено нотний стан з нотами, розташованими в терцію, Це свідчить про те, що церковний спів з часом був не тільки монодійний, а й у два голоси (в терцію). Далі в рукописі неодноразово на полях зустрічається зображення нотного стану, але вже без нот та будь-яких знаків. Останні аркуші рукопису мають сліди залиття [19].

Наступна Тріодь пісна (ф. 1, № 2813) написана приблизно в 90-ті роки XVI ст. загальна кількість аркушів 280. Текст написаний українським півуставом і супроводжується екфонетичними та невменними знаками. Формат рукопису Папір - $2^{\circ}$ (300 х 190). Почерк в рукописі один, чорнило темно-коричневе, кіновар. Оправа рукопису - дошка в коричневій шкірі з тисненням, нижня кришка тріснута по довжині. На верхній кришці по центру зображення розп'яття 3 двома Предстоячими. В кутах рамки євангелісти: зліва - св. Матфей, зправа - св. Іоанн. На форзаці скорописом написано «из с. Тырановкы Проскур». На вільному аркуші форзаца скорописом написано: «Изъ числа книг Бібліотеки Кіево-Михайловского монастиря 1861 г.». На вкладеному аркуші 3 шифром № 7875/1907 г. скорописом написано «Тріодь постная из церкви с. Тырановка. Доставлена священником с. Гаврилец». Перший аркуш рукопису починається із кіноварної заставки у вигляді плетінки. Заголовні ініціали виконані кіновар'ю з рослинним живописом. Кінцівки розділів (139 зв. та 279 зв.) рукопису виконані колофоном. Текст починається з Неділі про Митаря і Фарисея до Лазаревої суботи включно. Починаючи з 251 арк і до 279 зв. розміщений Устав великої вечірні, троїчні, сідальни, синтаксар на Великий піст [10].

Рукопис Тріодь пісна (ф. 307, № 430) реставрована на початку XVIII ст. Аркуші підклеєні біля корінця, обкладинка картонна, корінець та кути обкладинки 3 коричневої шкіри. Формат рукопису Папір $-4^{\circ}(185 \times 133)$, чорнило коричневе, кіновар. Текст написаний українським півуставом приблизно в другій половині XVI ст. Почерків два: 1 арк. - 161 зв. та 162 арк. - 286 зв. На форзаці і на 1 арк. є штамп «Бібліотека Кіево-Златоверхого-Михайлівского монастиря $189 \ldots$ г.». Текст починається з Утрені понеділка 3-ї седмиці Великого посту, закінчується службою п'ятниці 6-ї седмиці. Заголовки розділів написані кіноварною в'яззю із вказівкою гласу. На 1 арк. і на 1 зв. написано на нижньому полі українським скорописом «Сию книгу рекомую Тріодь постную купил раб Божий Ястреб Сенько». Запис дублюється польською мовою на 9-11 зв. Заголовні ініціали в рукописі виділені кіновар'ю та прикрашені рослинним живописом. На 176 зв. чорнилом зображено чаплю 3 підписом. Весь текст рукопису супроводжують екфонетичні та невменні знаки [18].

Тріодь цвітна (ф. 306, № 26) рукопис XVI ст., початок відсутній. Кількість аркушів 325, на яких подекуди залишилися сліди замокання. Текст написаний українським крупним, квадратним півуставом першої половини XVI ст. Рукопис неодноразово і неякісно реставрований, потребує нової реставрації. Формат рукопису Папір - $2^{\circ}(295$ х 190). Оправа дошка обтягнута коричневою шкірою 3 тисненням. Верхня обкладинка має тріснуту дошку навпіл, металеві застібки збереглися частково. На окремому аркуші надруковано «Тріодь цвітная, рукопись XVI векаю Листы 1-14 и 61-63 написаны в XVII и даже XVIII векахъ». Перший аркуш написаний скорописом на нижньому полі дата - 1863 г. Рукопис починається із Лазаревої суботи, закінчується уставними вказівками на літургію Неділі Всіх Святих. На бічному полі позначаються назви піснеспівів (троїчни, богородични, мученични) iз скороченням під титлом.

Сьомий аркуш рукопису починається із заставки 3 рослинним живописом. В центрі розташована чаша, з якої вправо і вліво виходять гілки з листками і квітами, а над чашею, по центру, знаходиться хрест. Заставка виконана чорнилами і кіновар'ю, що розташована в рамці заштрихованій коричневим фоном. Назва тексту під заставкою написана кіноварною в'яззю.

315 арк. починається текст XVI ст. 3 пісні канону утрені Лазаревої суботи. Закінчується текст статутними вказівками на літургію Неділі Всіх Святих. В тексті в XVII ст. виписки з Маркових глав та сполучення служб Благовіщенню з великопісними службами. Над текстом рукопису розташовані 
екфонетичні та невменні знаки. Вказівки на певний глас розташовані в тексті після заголовків та на бічних полях. Закінчення тексту в рукописі (325 арк.) оформлено у вигляді хреста. Наприкінці тексту зображена рука, яка тримає чашу над якою розташована квітка [17].

Тріодь цвіта (ф. 1, № 7484) написана приблизно в 30-40 pp. XVI ст. Рукопис має сліди реставрації, аркуші підклеєні біля корінця. Багато пошкоджених аркушів, деякі з них відпадають. Збірник потребує нової реставрації. Початок рукопису відсутній, втрачені перші два зошити. Загальна кількість збережених аркушів 328. Оправа рукопису - дошка із залишками шкіри. Формат рукопису Папір - 20 (295 х 190). Текст написаний українським півуставом першої половини XVI ст. Простежується два почерки: перший - широкий прямий з 1 арк. - 174 арк.; другий.. почерк більш вузький $з$ нахилом вправо 3174 зв. по 327 зв. Рукопис написаний темно-коричневим, світлокоричневим чорнилом і кіновар'ю. Заголовки рукопису оздоблені кіноварною в'яззю. На форзаці $\epsilon$ запис скорописом «с. Бузаки Ковельск. у. экскурсія Д. Щербаковс. 1910 г.». Заголовні ініціали виділені кіновар'ю та оздоблені рослинним живописом. Кінцівки розділів орнаментовані смужками у вигляді ламаної лінії та крапок. Рукопис починається з богослужіння з Неділі ваій до Неділі Всіх Святих включно. В рукописі на аркушах 1, 4, 31 та ін. є штамп «Кіевский музей Імператора Николая II» [11].

Тріодь цвітна (ф. 301, № 143 л.) написана приблизно в 70-80 pp. XVI ст. Рукопис зберігся частково, загальна кількість - 91 арк. Оправа не зберіглася, Формат рукопису Папір - $2^{\circ}$ (270 х 170). Текст рукопису написаний раннім українським півуставом XVI ст. і складається з уривків тріодей XVI і XVII ст. Над текстом рукопису розташовані екфонетичні та невменні знаки. На 1 арк. зверху на лівому полі скорописом написано «Муз. Рук. 644». Заголовки розділів виділені кіновар'ю. Рукопис написаний світло-коричневим та коричневим чорнилами, має сім почерків. У колонтитулі на верхньому полі на розвороті міститься рубрикація седмиці та дня. Початок читання на богослужінні виділений заголовним кіноварним ініціалом. Епізодично трапляється рубрикація стихів та гласів.

Кінцівки розділів оформлені колофонами (17 арк., 33 зв., 42 арк., 58 зв., 61 зв.). На 17 арк. поряд 3 колофоном, праворуч, зображено два обличчя. До першого обличчя, яке більше за розміром домальовані дві руки, а на голові шапка, чи корона. Поруч намальоване обличчя, меншого розміру, також має подібний головний убір. Під цими малюнками текст написаний польським скорописом. Ще нижче розташований малюнок виконаний чорнилом - рука тримає плетінку малих розмірів. Поруч інший малюнок виконаний світло-коричневим чорнилом - рука тримає квітку. 3 лівого боку під колофоном текст написаний українським скорописом. Внизу аркуша, по центру сторінки світлим чорнилом написано «Со ітымъ Б(о)гомь конецъ». Малюнок чаша з рукою зустрічається на 58 зв. під колофоном. Зміст рукопису - це розрізнені уривки тріоді цвітної починаючи із стихіри воскресної «Радости вся исполнисашеся».Текст рукопису закінчується читанням пророчеств Ісайї на великій вечерні Неділі Всіх Святих [16].

Тріодь цвітна (ф. 312, № 82) написана наприкінці XVI ст. Рукопис зберігся повністю, загальна кількість - 340 арк. Рукопис неодноразово реставрований, про що свідчать обкладинка і реставровані та підклеєні аркуші. Обкладинка рукопису картонна з наклеєними трикутними і корінцем з темнокоричневої шкіри. На форзаці є штамп «Бібліотека Кіево-Софійскаго Собора № 89». Текст написаний українським півуставом кінця XVI ст., Формат рукопису Папір - $2^{\circ}$ (270 х 180). Над текстом рукопису розташовані екфонетичні та невменні знаки. В основному почерк один, але фрагментарно зустрічаються ще два почерки. Текст написаний блідо-коричневим чорнилом і кіновар'ю. Заголовки розділів написані кіноварною в'яззю $з$ вказівкою певного гласу виконання піснеспівів. Заголовні кіноварні ініціали прикрашені рослинним живописом у вигляді завиток, розчерків та крапок. Текст рукопису починається з стихіри шостої седмиці Великого посту, закінчується одпустою літургії Неділі Всіх Святих. Весь рукопис супроводжують екфонетичні та невменні знаки, які проставлені як над текстом так і на бічних полях рукопису. На 48-50 арк. українським скорописом написано «Сия книга рекомая тріодь цветная купил еи раб божий Стефан Мимохуд своє спущение грехов из жоною своєю Іриною». На 340 зв., наприкінці тексту з лівого боку є два малюнки світло-коричневим та блідим чорнилом. Вони зображують дві руки які тримають чаші. Можливо ці малюнки більш пізні і дублюють оригінальний малюнок, який втрачений після реставрації. Нижня частина аркушу заклеєна двома білими квадратними аркушами, які перекривають можливий оригінальний малюнок і частину тексту, що написаний українським скорописом. На нижньому наклеєному білому аркуші стоїть штамп «Бібліотека Кіево-Софійскаго Собора № ...» [20].

Наукова новизна. В рукописних збірниках Тріодях виявлено певні відмінності: в оформленні тексту, а саме гравюр, заставок, заголовків, ініціалів, колофонів. Простежено поступову модернізацію українського півуставу, який пройшов шлях від великого та біглого півуставу до скоропису. 
Екфонетичний та невменний нотопис в рукописних Тріодях, який проставлений над текстом і на бічних полях є доволі варіативним, на відміну від зазначених гласів.

Висновки. Археографічний опис рукописних Тріодей XVI ст. із колекції Інституту рукопису Національної бібліотеки України імені В. І. Вернадського дав змогу виявити загальні риси в оформленні стародавніх півчих збірок - тексти рукописних збірників написані українським півуставом. Кожний розділ починається заголовком, який написаний кіноварною в'яззю. Відповідно закінчення кожного розділу має певне оформлення у вигляді колофону чи будь-яких фігур (хреста, чаші), або невеликими графічними зображеннями, де використовуються крапки, коми, хвилясті лінії, хрестики тощо. Потрібно визначити і певні відмінності в півчих рукописах, а саме: в оформленні тексту та поступовій модернізації українського півуставу. Екфонетична і невменна нотації в півчих рукописних збірниках має певну варіативність, що не засуджувалось Православною церквою. Натомість будь-яка варіативність по відношенню до текстів богослужіння була недопустима, так як вони були канонічними. Невирішеним залишається питання розшифровки екфонетичного та невменного нотопису, який супроводжує тексти Пісних та Цвітних Тріодей. Подальші грунтовні дослідження півчих рукописних збірок української Православної церкви наблизять вченихмедієвістів до розшифрування та перекладення їх на сучасну нотацію.

\section{Jimepamypa}

1. Православная энциклопедия. Григорианское пение. URL: http://www.pravenc.ru/text/166507.html.

2. Жолтовський П. М. Українська рукописна книга та її оздоблення. Харків, 1926. 214 с.

3. Іванова О. А. Кирилична рукописна книга XVI ст. 3 фондів Інституту рукопису Національної бібліотеки України імені В.І. Вернадського : Історико-кодикологічне дослідження. Альбом філіграней, відп. ред. Л.А. Дубровіна. Київ: НБУВ, 2016. 256 с.

4. Іванова О. А., Дубровіна Л. А. Півчі богослужбові книги у репертуарі рукописних книг XVI ст. у фондах Інституту рукопису Національної бібліотеки України імені В. І. Вернадського // Рукописна та книжкова спадщина України. 2003. Вип. 8. С. 71-79.

5. Разумовский Д. В. Церковное пение в России. Москва. 1-й вып. 1867; 2-й вып. 1868; 3-й вып. 1869. Всего во всех трех выпусках. 362 с.

6. Свенціцький I. С. Прикраси рукописів Галицької України XVI-ого віку // Збірки Нац. Музею у Львові. Жовква, 1922. Ч. 137. С. 1-7.

7. Триодь Постная и Цветная. URL: https://ruvera.ru/triod.

8. Ц Цветная триодь. Часть 1. URL: https://imwerden.de/publ-1321.html

9. Щербаківський Д. М. Золотарська оправа книжки в XVI-XIX століттях на Україні // Бібліологічні вісті. 1924. № 1-3. С. 3-15.

10. НБУВ, ф. 1, № 2813. Тріодь пісна рукопис XVI ст.

11. НБУВ, ф. 1, № 7484. Тріодь цвітна рукопис XVI ст.

12. НБУВ, ф. 235, № 14. Тріодь пісна рукопис XVI ст.

13. НБУВ, ф. 235, № 15. Тріодь пісна рукопис XVI ст.

14. НБУВ, ф. 235, № 16. Тріодь пісна рукопис XVI ст.

15. НБУВ, ф. 235, № 17. Тріодь пісна рукопис XVI ст.

16. НБУВ, ф. 301, № 143 л. Тріодь цвітна рукопис XVI ст.

17. НБУВ, ф. 306, № 26. Тріодь цвітна рукопис XVI ст.

18. НБУВ, ф. 307, № 430. Тріодь пісна рукопис XVI ст.

19. НБУВ, ф. 312, № 74. Тріодь пісна рукопис XVI ст.

20. НБУВ, ф. 312, № 82. Тріодь цвітна рукопис XVI ст.

\section{References} Russian].

1. The Orthodox Encyclopedia. Gregorian singing. (2011). URL: http://www.pravenc.ru/text/166507.html [in

2. Zholtovsky, P. M. (1926). Ukrainian manuscript book and its decoration. Kharkiv. [in Ukrainian].

3. Ivanova, O. A. (2016). Cyrillic Cyrillic manuscript book of the XVI century from the holdings of the Institute of Manuscripts of the National Library of Ukraine V.I. Vernadsky: Historical and codicological study. Filigree Album. Rep. ed. L.A. Dubrovina. Kyiv: NBUV. [in Ukrainian].

4. Ivanova, O. A., Dubrovina, L. A. (2003). Semi liturgical books in the repertoire of manuscripts of the XVI century. in the holdings of the Institute of Manuscripts of the V.I. Vernadsky National Library of Ukraine. Manuscript and book heritage of Ukraine. Issue 8. pp. 71-79. [in Ukrainian]. Russian].

5. Razumovsky, D. V. Church singing in Russia. Moscow. 1st issue 1867; 2nd issue 1868; 3rd issue 1869. [in

6. Sventcitsky, I. S. (1922). Decorations of manuscripts of Galician Ukraine of the 16th century. Collections Nat. Museum in Lviv. Zhovkva, Vol. 137. pp. 1-7. [in Ukrainian]. 